TKACHUK H.

Khmelnytskyi National University, ,Ukraine

\title{
THE MONITORING OF THE QUALITY OF LEARNING CHEMISTRY AS A BASIC EDUCATIONAL DISCIPLINE IN THE HIGHER EDUCATION SYSTEM
}

The monitoring of the quality of higher education over the past 2 to 3 decades has developed significantly, which is characterized by a systemic nature. However, currently, there is a situation in which important system-forming factors that determine the quality of training specialists remain on the sidelines of the monitoring process. In particular, this applies to learning as one of the two main components of the educational process. It so happened that learning as an extremely important process was hidden in the shadow of what is called independent work of students in the educational and pedagogical practice of universities. This is why the learning mechanism itself was left out of monitoring the educational process, which is a drawback of it as a system. The author identified and systematized the functional components of the learning quality, identified the influence of various factors on the effectiveness of learning as a didactic process and revealed the mechanism of their influence on the management of the learning process on an example of teaching chemical disciplines. The obtained results of theoretical studies with the use of matrix algebra allow presenting them for realization of rather simple schemes and applying in practice. Based on these results, the conclusions are formulated, which is very important in terms of improving the elements of the learning technology in training chemists and chemists-technologists. A concept of the learning technology matrix was introduced for the first time and the possibility of its application to manage the learning process is shown. The educational and laboratory base of the Department of Chemistry and Chemical Engineering of Khmelnytskyi National University, as well as educational and methodical and scientific publications of the author on chemical disciplines, were used. The proposed system of monitoring the quality of the technological process of learning using a matrix representation of results allows you to: create a comprehensive system of qualitative and quantitative assessment of the technological process of learning, which presents the internal modular structure of new components and their elements and illustrates their interaction; identify problem areas in the learning process and the reasons that cause them; substantiate proposals for actions to be taken for ensuring the appropriate quality of learning.

Key words: learning, learning technology, structural elements of the learning technology, learning technology matrix, learning quality, learning quality monitoring

Стаття надійшла до редакції 11.08 .2020 р.

УдК 378.011.3-051:74

DOI: https://doi.org/10.33989/2075-146x.2020.25.223332

ЦЗІ ЛЕЙ

ORCID: 0000-0002-6446-0327

Національний педагогічний університет імені М.П. Драгоманова
НАУКОВО-ПЕДАГОГІЧНІ ПІДХОДИ ДО ФОРМУВАННЯ КУЛЬТУРИ ХУДОЖНЬО- ПЕДАГОГІЧНОГО СПІЛКУВАННЯ МАЙБУТНІХ УЧИТЕЛІВ ОБРАЗОТВОРЧОГО МИСТЕЦТВА

\footnotetext{
У статті визначено та обгрунтовано науково-педагогічні підходи до формування культури художньо-педагогічного спілкування майбутніх учителів образотворчого мистецтва: культурологічний, аксіологічний, компетентнісний, особистісно-орієнтований.

Ключові слова: культура художньо-педагогічного спілкування, науково-педагогічний підхід, культурологічний, аксіологічний, компетентнісний, особистісно-орієнтований науковопедагогічні підходи
}

Постановка проблеми. Реалізація стратегічних завдань освітньої політики й подальшої еволюції вищої школи потребує суттєвого підвищення якості підготовки освітянських кадрів у сфері культури педагогічної комунікації як важливої детермінанти налагодження продуктивних суб'єктних відносин учасників освітнього процесу, розбудови системи педагогічного партнерства. Особливо це стосується підготовки мистецько-педагогічних кадрів, зокрема майбутніх учителів образотворчого мистецтва, для успішної професійної діяльності яких культура художньопедагогічного спілкування перетворюється на базову передумову дієвої реалізації культуротворчого, виховного, розвивального потенціалу образотворчого мистецтва у роботі з учнівською молоддю. Це вимагає створення надійної науково-методичної бази формування культури художньо-педагогічного спілкування майбутнього вчителя образотворчого мистецтва, а саме визначення комплексу науково-педагогічних підходів як фундаментальної основи педагогічної організації цього процесу. 
Аналіз найвагоміших публікацій... Досягнення сучасної філософсько-естетичної, мистецтвознавчої, психолого-педагогічної думки становлять солідну джерельну базу нашого дослідження. Концептуальні засади науково-педагогічної методології розроблені у роботах В.Бондаря, С.Гончаренка, В.Краєвського, В.Сластьоніна та ін., а конкретні методологічні стратегії запропоновані багатьма вченими залежно від обраних векторів їх досліджень. Мистецтво як своєрідна форма естетичного освоєння світу та особливий вид людської діяльності в системі художньої комунікації досліджується у працях Л. Виготського, О. Леонтьєва, Є. Назайкінського, Є. Олесіної, Я. Пономарьова, О. Ростовського, О. Рудницької, Е. Сепіра, Г. Тарасова, Л. Феррари та ін. Окремі питання художньо-педагогічного спілкування дотично вивчаються у дослідженнях В. Андрущенка, О. Арнольдова, М. Бахтіна, С. Бондаревської, Л. Заніної, В. Кан-Каліка, В. Сластьоніна, . Чечель, Є. Шиянова, С. Франк, М. Хайдеггера, К. Ясперса та ін., у яких культура спілкування розглядається і як важливий компонент загальної культури особистості і як складова педагогічної культури учителя-вихователя. Особливу значущість для науковометодичного розв'язання проблеми формування культури художньо-педагогічного спілкування майбутнього вчителя образотворчого мистецтва становлять наукові розвідки Ю. Борєва, М. Кагана, Ю. Петрової, О. Апраксіної, І. Зязюна, Н. Кузьміної, Л. Коваль, В. Петрушина та ін., зокрема розроблені зазначеними авторами положення щодо певних аспектів художньо-педагогічного спілкування та естетичної комунікації.

Вирізнення досі не вирішених аспектів... Попри схарактеризований значний пласт наукових розробок досліджуваної проблеми здебільшого у розрізі наукознавства, філософії, мистецтвознавства, загальної теорії комунікації, водночас було встановлено відсутність системних педагогічних досліджень, безпосередньо присвячених визначенню науково-педагогічних підходів до формування культури художньо-педагогічного спілкування майбутніх учителів образотворчого мистецтва.

Мета статті полягає у створенні науково-методологічної бази формування культури художньо-педагогічного спілкування майбутніх учителів образотворчого мистецтва, а ії завданнями виступають виокремлення конкретних науково-педагогічних підходів до організації цього процесу та обгрунтування їх евристичних можливостей.

Виклад основного матеріалу. Вироблений у результаті аналізу досягнень сучасної науково-методологічної педагогічної думки власний погляд на визначення комплексу базових науково-педагогічних орієнтирів формування художньо-педагогічного спілкування майбутнього вчителя образотворчого мистецтва полягає у виокремленні й обгрунтуванні культурологічного, аксіологічного, компетентнісного та особистісно-орієнтованого підходів як достатньо продуктивних, на нашу думку, педагогічних стратегій, найбільш адекватних як особливостям феноменології культури художньо-педагогічного спілкування, художньо-педагогічної діяльності вчителя образотворчого мистецтва, так і завданням художньо-естетичного виховання учнів.

Чільне місце серед науково-педагогічних підходів до формування культури художньо-педагогічного спілкування майбутніх учителів образотворчого мистецтва посідає культурологічний підхід, концептуальні положення якого глибоко розкрито у працях І. Балхарової, Є. Бондаревської, О. Газмана, В. Гури, М. Кагана, І. Колмолгорової Н. Крилової, А. Погодіної, Є. Фортунатової, Н. Щуркової та ін., у яких вивчаються різноманітні ракурси його евристичних можливостей. Серед них привертає увагу розуміння культурологічного підходу як сукупності методологічних прийомів, які забезпечують аналіз будь-якої сфери соціального та психічного життя, зокрема сфери освіти й педагогіки, крізь призму таких системотвірних культурологічних понять як-от: культура, культурні зразки, норми й цінності, уклад і спосіб життя, культурна діяльність та інтереси тощо (Масленнікова, 2013).

Ю. Бойчук у сутності культурологічного підходу вбачає специфічне вивчення світу людини в контексті ії культурного існування, в аспекті того, чим світ є для людини, яким сенсом він для неї наповнений, якими характеризується зв'язками людини з культурними цінностями, наявними культурними програмами, культурною наповненістю реальності. На думку вченого людина містить у собі частину культури і розвивається на основі засвоєної нею культури та при цьому людина вносить у неї принципово нові положення, стає творцем нових елементів культури. Освоєння ж людиною культури як системи цінностей є розвитком самої людини та іï становлення як творчої особистості (Бойчук, 2009). М. Каган зазначає, що людина використовує, відтворює та творить культуру, тим самим створює себе як суб'єкта культури, втілюючи себе в ній (Каган, 1996). На думку ж I. Ісаєва, саме культурологічний підхід забезпечує зв'язок людини з культурою як системою цінностей (Ісаєв, 2010).

Щодо проблем педагогічної освіти, на думку О. Падалки, зазначений підхід являє собою сукупність теоретикометодологічних положень й організаційно-педагогічних заходів, спрямованих на забезпечення умов для оволодіння майбутнім вчителем змістом педагогічної культури і розвитку вчителя як ії суб'єкта (Аніщенко, Падалка, 2013).

Звернення до положень культурологічного підходу в дослідженні культури художньо-педагогічного спілкування майбутнього педагога-художника дозволяе підходити до процесу формування культури художньо-педагогічного спілкування майбутніх педагогів як іiі компетентних носіїв та активних суб'єктів, що передбачає розуміння сутності цього аспекту педагогічної діяльності як культурологічного явища і феномену, засвоєння студентами сукупності культурологічних понять й соціально-культурних норм, вироблення індивідуальних професійних культурних орієнтирів організації художньо-педагогічного спілкування задля успішної особистісно-професійної самореалізації.

Важливим для нашого дослідження науково-педагогічним підходом, органічно й логічно дотичним до попереднього, є аксіологічний підхід, який акцентує увагу на дослідженні ціннісно-смислової сфери особистості. Проблема цінностей займає важливе місце у наукових розробках зарубіжних та вітчизняних дослідників: К. Абульханової-Славської, Н. Асташової, І. Беха, І. Бужиної, Л. Буєвої, 3. Васильєвої, С. Гончаренка, В. Гриньової, Л. Демінської, І. Зязюна, І І. Ісаєва, Т. Калюжної, В. Крутецького, В. Мясищева, В. Огнев’юка, О. Савченко, М. Сметанського, Г. Щедровицького та ін. Аксіологічний підхід передбачає формування в особистості ціннісних орієнтацій, які задають загальну спрямованість іï інтересам і прагненням, ієрархію індивідуальних переваг, мотиваційну програму діяльності тощо (Садова, 2010); дозволяє через сучасні пріоритети, засновані на традиційних і нових цінностях вітчизняної освіти, підкреслити центральне місце людини в педагогічній системі (Бойчук, 2017 , с. 120); сприяє інтеграції культури з духовною сферою життєдіяльності особистості (Рудницька, 2005). 
На думку вчених, беззаперечне значущість аксіологічного підходу у підготовці майбутніх вчителів мистецьких дисциплін пояснюється тим, що завдяки взаємодії особистості з певною системою цінностей, зокрема художніх, та усвідомленому їх впливу на вихованців забезпечується позитивний результат, високий рівень розвитку художньоціннісних орієнтацій шкільної молоді (Жигінас, 2016, с. 87-88); створюються сприятливі умови для розвитку емоційно-ціннісних переживань і ціннісних ставлень кожного суб'єкта взаємодії з мистецтвом (Зайцева, 2017, c. 176). Нам імпонує теза Т. Жигінас, що аксіологічний підхід полягає у залученні вчителя до методологічних, теоретичних і прикладних знань про цінності, про їх природу, механізми розвитку та способи функціонування, а також про професійно-педагогічні цінності, що характеризують професійне становлення і самовдосконалення особистості сучасного вчителя (Жигінас, 2016, с. 88).

Застосування можливостей аксіологічного підходу до формування культури художньо-педагогічного спілкування майбутніх учителів образотворчого мистецтва спрямовує на вироблення у студентів-художників ціннісного ставлення до майбутньої професії та до себе як творця духовного світу, усвідомлення фундаментальних і прикладних загальнолюдських та мистецьких культурних цінностей як основи продуктивного художньопедагогічного спілкування, що набуває особистісного сенсу.

Науково-методичні засади формування культури художньо-педагогічного спілкування майбутніх учителів образотворчого мистецтва також грунтуються на компетентнісному підході як єдиної сучасної системи визначення мети, відбору змісту та організаційного забезпечення процесу підготовки фахівця на основі виокремлення спеціальних, загальних і ключових компетенцій, що забезпечують результативність його майбутньої професійної діяльності. Його концептуальні засади викладено в працях О. Андрєєва, І. Беха, Н. Бібік, Л. Ващенко, О. Дубасенюк Ф. Зеєра, І. Зимньої, І. Єрмакова, О. Локшиної, О. Овчарук, Л. Паращенко, О. Пометун, О. Савченко, С. Трубачової, Л. Хоружої, А. Хуторського та ін.

Компетентнісний підхід орієнтує як на формування та розвиток ключових і предметних компетентностей особистості студентів, результатом якого буде формування загальної компетентності людини як інтегрованої характеристики особистості, що має сформуватися у процесі навчання і містити знання, вміння, ставлення, досвід діяльності й поведінкові моделі особистості (Овчарук, 2004), так і на неперервне особистісне самовдосконалення. Так, О. Андрєєв (Андрєєв, 2005) вважає, що зазначений підхід дозволяє студенту вільно та самостійно застосовувати набуті знання й накопичений досвід у різних обставинах та умовах життєдіяльності.

Отже, компетентнісний підхід дозволяє студентам у процесі здобуття майбутньої професії не тільки засвоїти знання, набути необхідних вмінь і опанувати потрібними для подальшої діяльності навичками, а й розвинути здатність до продуктивних дій у швидко плинних ситуаціях для того, щоб вчасно побачити й осмислити нові відкриття і винаходи, знайти потрібну інформацію, підвищити свою кваліфікацію тощо. До того ж реалізація компетентнісного підходу передбачає комплексне засвоєння студентами знань i умінь, що пояснюється спрямованістю на виховання конкурентоспроможної особистості, яка прагне до творчого виконання своїх професійних обов'язків і особистісно-професійного розвитку.

Аналіз освітнь--професійної програми бакалаврату, що забезпечує підготовку майбутніх учителів образотворчого мистецтва, галузі знань 01 Освіта/Педагогіка, спеціальності 014 Середня освіта (образотворче мистецтво) дозволяє виокремити серед спеціальних (фахових, предметних) компетентностей за спеціальністю, якими має володіти випускник відповідного напрямів підготовки 3 сформованою культурою художньопедагогічного спілкування, комунікативну компетентність, зміст якої полягає у:

- вияві знань змісту сучасної термінології образотворчого мистецтва; класифікацію видів, жанрів образотворчого мистецтва; особливості основних напрямів образотворчого мистецтва; тенденцію розвитку світового й національного образотворчого мистецтва;

- дотриманні особливостей основних напрямів образотворчого мистецтва;

- вияві тенденції розвитку світового й національного образотворчого мистецтва;

- використанні теоретичних основ рисунку, живопису, композиції, декоративно-прикладного мистецтва та етнодизайну;

- висловлюванні думок для успішного розв'язання проблем і завдань у професійній діяльності образотворчого мистецтва;

- здійсненні технології роботи різними графічними, пластичними і живописними матеріалами;

- здійсненні конструктивної взаємодії в різних видах комунікації (професійній, навчальній, безпосередній та опосередкованій);

- усвідомленні себе як носія мовної культури;

- постійній демонстрації зразків дотримання норм культурної комунікації.

Як бачимо, реалізація компетентнісного підходу у дослідженні культури художньо-педагогічного спілкування дозволяє визначити іï як одну з ключових загальнокультурних й професійних компетенцій майбутнього вчителя образотворчого мистецтва, що забезпечує здатність організувати особливе середовище, у якому майбутній педагогхудожник повинен бути готовим до творчої співпраці, діалогічного мислення, володіти навичками командної роботи і ділового спілкування, науковими основами міжособистісного та професійного спілкування; демонструвати художньо-комунікативні компетенції сприйняття, аналізу, оцінювання та ретрансляції навчальної інформації, пов'язаної з образотворчим мистецтвом та художньо-педагогічною діяльністю.

В обгрунтуванні методичних основ, що забезпечують результативність формування культури художньопедагогічного спілкування майбутніх учителів образотворчого мистецтва, визначальне місце займає особистісноорієнтований підхід, який з точки зору сучасної науково-педагогічної методології дозволяє виявити особистісну специфіку діяльності учасників процесу на основі взаємоповаги, довіри, а також показати роль і місце суб'єктів освітнього процесу і забезпечити розкриття і максимальне використання суб'єктного досвіду (Дубасенюк, 2012, c. 18). Особистісно-орієнтований підхід, на думку Г.Шишкіна (Шишкін, 2013), - це методологічна орієнтація в 
педагогічній діяльності викладачів педагогічного університету, яка, опираючись на систему взаємопов'язаних понять, ідей та способів дій, підтримує і забезпечує процеси самопізнання, самовдосконалення та самореалізації особистості студента як майбутнього педагога. При використанні даного підходу викладач докладає основні зусилля для розвитку в кожному студенті унікальних особистісних якостей майбутнього професіонала.

Дослідженню різноманітних аспектів особистісно-орієнтований підходу присвячені роботи учених М. Алексєєва, Є. Бондаревської, О. Газмана, Л. Лузіної, О.Пєхоти, В. Сєрікова, Є. Степанова, Н. Тимощук, А. Хуторського, І. Якиманської та ін., які грунтуються на філософсько-психологічних теоріях особистості та визнанні активної природи людини. Це підкреслює значення особистості учителя-вихователя, його суб'єктних особистісних якостей і властивостей у педагогічному процесі та наголошує на важливості врахування неповторних індивідуальних особливостей студентів, їх потреб, інтересів, здібностей у формуванні їх культури художньопедагогічного спілкування. Тому нам імпонує твердження І. Якіманської, що в основі особистісно-орієнтованого підходу лежить визнання індивідуальності, самоцінності кожної людини, їі розвитку не як колективного об'єкту, але, перш за все, як індивіда, наділеного своїм неповторним суб'єктивним досвідом (Якіманська, 2000).

Аргументуючи доцільність застосування особистісно-орієнтованого підходу у галузі мистецької освіти, О. Дубасенюк вказує на його орієнтацію на особистісні власні життєві смисли людини, що навчається, врахування іiі мотивації, інтересів, потреб і реальних можливостей (Дубасенюк, 2012, с. 228). За словами науковця, формування професійної готовності майбутніх учителів у галузі мистецької освіти в умовах особистісно-орієнтованого підходу базується на індивідуально-творчому розвитку особистості фахівця, що передбачає не запам'ятовування та репродукування інформації, а іiї творчу трансформацію, знаходження в ній особистісного сенсу, формування до неї особистісного ставлення, розуміння виховної потужності художньо-педагогічних ідей, теорій, методичних рекомендацій. Таким чином, у професійній художньо-педагогічній діяльності майбутній учитель повинен трансформувати особистісні надбання у галузі мистецтва та намагатися відкрити пріоритети особистісного ставлення до кожного учня (Дубасенюк, 2012, с. 229).

Використання особистісно-орієнтованого підходу у формуванні культури художньо-педагогічного спілкування майбутніх вчителів образотворчого мистецтва уможливлює їх повноцінну особистісну самореалізацію, розвиток особистісних якостей, здібностей, потенційних можливостей у професійно-комунікативній сфері, розуміння особливостей індивідуального комунікативного розвитку, потреб та мотивів художньо-педагогічного спілкування для забезпечення ефективності художньо-педагогічної комунікації.

Висновки. Таким чином, визначені та обгрунтовані у дослідженні науково-педагогічні підходи до формування культури художньо-педагогічного спілкування майбутніх учителів образотворчого мистецтва становлять фундаментальну методологічну базу організації цілеспрямованих педагогічних впливів. На нашу думку, процес формування культури художньо-педагогічного спілкування майбутніх педагогів-художників відбуватиметься ефективніше за умови комплексної реалізації культурологічного, аксіологічного, компетентісного та особистісноорієнтованого підходів та їх інтеграції у цілісну динамічну систему. Використання вище розглянутих науковопедагогічних підходів для розроблення методичних засад педагогічної організації процесу формування культури художньо-педагогічного спілкування майбутніх учителів образотворчого мистецтва дозволить не лише цілісно вивчати проблеми професійної підготовки майбутніх учителів цього фаху, успішно формувати готовність студентів до художньо-педагогічної комунікації, а й надасть їм можливість виробити систему художньо-комунікативних норм, знань, умінь і цінностей, що реалізується у процесі взаємодії педагога з усіма учасниками навчальновиховного процесу, спрямованої на створення таких комунікативних зв'язків та відносин, які найбільшою мірою відповідають сутності образотворчого мистецтва, сприяють усвідомленню його художньо-образного змісту та специфіки засобів художньо-естетичної виразності, а також створюють оптимальні умови для духовного розвитку вихованців.

Подальшим напрямом дослідження бачиться проектування на основі визначених науково-педагогічних підходів комплексу педагогічних принципів умов та методичного забезпечення формування культури художньопедагогічного спілкування майбутніх учителів образотворчого мистецтва.

\section{Список використаних джерел}

Андреев, А. Л. (2005). Компетентностная парадигма в образовании: опыт философско-методологического анализа. Педагогика, 4, 19-27.

Аніщенко, В. О., Падалка, О. С. (2013). Культурологічний підхід у професійній підготовці вчителя. Освіта дорослих: теорія, досвід, перспективи, 6, 103-107.

Бойчук, В. М. (2017). Теоретичні та методичні основи художньо-графічної підготовки майбутнього вчителя технологій. (Дис. д-ра пед. наук). Вінниц. держ. пед. ун-т ім. М. Коцюбинського. Вінниця.

Бойчук, Ю. Д. (2009). Культурологічний і аксіологічний підходи до формування еколого-валеологічної культури студентів педагогічних навчальних закладів. Вісник НТУУ «КПI», 3, 121-125.

Дубасенюк, О. А. (Ред.). (2012). Професійна педагогічна освіта: особистісно орієнтований підхід. Житомир: Вид-во ЖДУ ім. І. Франка. 
ISSN: Print 2075 - 146X, Online 2616-6623. Витоки педагогічної майстерності. 2020. Випуск 25

Жигінас, Т.В. (2016). Аксіологічний підхід у підготовці майбутніх учителів музичного мистецтва до просвітницької роботи. Духовність особистості: методологія, теорія і практика, 5 (74), 85-94.

Зайцева, А.В. (2017). Методична система формування художньо-комунікативної культури майбутнього вчителя музики. (Дис. канд. пед. наук). Національний університет імені М. П. Драгоманова. Київ.

Ісаєв, I. Ф. (2010). Професійно-педагогічна культура як предмет наукового дослідження. Теоретичні питання культури, освіти та виховання, 42, 143-147. Взято з http://nbuv.gov.ua/UJRN/Tpkov_2010_42_40.

Каган, М. С. (1996). Философия культуры. Санкт-Петербург: Петрополис.

Лозова, В. І. (Ред.). (2012). Наукові підходи до педагогічних досліджень. Харків: Вид-во Віровець А. П.Ж: Апостроф.

Масленникова, С. Ф. (2013). Роль культурологического подхода в воспитании студентов. Apriori, 1, 1-8.

Овчарук, О. В. (Ред.). (2004). Компетентнісний підхід у сучасній освіті: світовий досвід та украӥнські перспективи. Київ: K.I.C.

Освітньо-професійна програма Образотворче мистецтво. Рівень вищої освіти: перший (бакалаврський), галузь знань 01 Освіта/Педагогіка, спеціальність 014 Середня освіта (образотворче мистеитво). (2017). Взято 3 http://smc.hnpu.edu.ua/files/Profili_OP/Profil_OP_\%20Obrazotvorche_mystetstvo_Bakalavr.pdf

Рудницька, О. П. (2005). Педагогіка загальна та мистещька. Тернопіль: Навч. книга-Богдан.

Садова, Т. (2010). Аксіологічний підхід у системі педагогічної методології. Дошкільна освіта, 1 (27), 63-69.

Шишкін, Г. О. (2013). Особистісно-орієнтоване навчання майбутніх учителів технологій. Науковий часопис Національного педагогічного університету імені М. П. Драгоманова, 5 (40), 292-297.

Якиманская, И. С. (2000). Технология личностно-ориентированного образования. Москва: Сентябрь.

\section{References}

Andreev, A. L. (2005). Kompetentnostnaia paradigma v obrazovanii: opyt filosofsko-metodologicheskogo analiza [Competence paradigm in education: the experience of philosophical and methodological analysis]. Pedagogika [Pedagogy], 4, 19-27 [in Russian].

Anishhenko, V. O., \& Padalka, O. S. (2013). Kulturolohichnyi pidkhid u profesiinii pidhotovtsi vchytelia [Culturological approach in teacher training]. Osvita doroslykh: teorija, dosvid, perspektyvy [Adult education: theory, experience, prospects], 6, 103-107 [in Ukrainian].

Boichuk, V. M. (2017). Teoretychni ta metodychni osnovy khudozhno-hrafichnoi pidhotovky maibutnoho vchytelia tekhnolohii [Theoretical and methodical bases of art and graphic training of the future teacher of technologies]. (D diss.). Vinnyc. derzh. ped. un-t im. M. Kocjubynsjkogho, Vinnycja [in Ukrainian].

Boichuk, Ju.D. (2009). Kulturolohichnyi i aksiolohichnyi pidkhody do formuvannia ekoloho-valeolohichnoi kultury studentiv pedahohichnykh navchalnykh zakladiv [Culturological and axiological approaches to the formation of ecological and valeological culture of students of pedagogical educational institutions]. Visnyk NTUU «KPI» [Bulletin of NTUU "KPI"], 3, 121-125 [in Ukrainian].

Dubasenjuk, O. A. (Red.). (2012). Profesiina pedahohichna osvita: osobystisno oriientovanyi pidkhid [Professional pedagogical education: a personality-oriented approach]. Zhytomyr: Vyd-vo ZhDU im. I. Franka [in Ukrainian].

Isaiev, I. F. (2010). Profesiino-pedahohichna kultura yak predmet naukovoho doslidzhennia [Professional and pedagogical culture as a subject of scientific research]. Teoretychni pytannia kultury, osvity ta vykhovannya [Theoretical issues of culture, education and upbringing], 42, 143-147. Retrieved from http://nbuv.gov.ua/UJRN/Tpkov_2010_42_40 [in Ukrainian].

Kagan, M. S. (1996). Filosofiia kultury [Philosophy of culture]. Sankt-Peterburg: Petropolis [in Russian]. 
Lozova, V. I. (Ed.). (2012). Naukovi pidkhody do pedahohichnykh doslidzhen [Scientific approaches to pedagogical research].

Kharkiv: Vyd-vo Virovecj A. P. “Apostrof” [in Ukrainian].

Maslennikova, S. F. (2013). Rol kulturologicheskogo podkhoda v vospitanii studentov [The role of the culturological approach in the education of students]. Apriori, 1, 1-8 [in Russian].

Ovcharuk, O.V. (Red.). (2004). Kompetentnisnyi pidkhid u suchasnii osviti: svitovyi dosvid ta ukrainski perspektyvy [Competence approach in modern education: world experience and Ukrainian perspectives]. Kyiv: K.I.S. [in Ukrainian].

Osvitno-profesiina prohrama Obrazotvorche mystetstvo. Riven vyshchoi osvity: pershyi (bakalavrskyi), haluz znan 01 Osvita/Pedahohika, spetsialnist 014 Serednia osvita (obrazotvorche mystetstvo) [Educational and professional program Fine Arts. Higher education level: first (bachelor), field of knowledge 01 Education / Pedagogy, specialty 014 Secondary $\begin{array}{llll}\text { education } & \text { (fine } & \text { (2017). } & \text { Retrieved }\end{array}$ http://smc.hnpu.edu.ua/files/Profili_OP/Profil_OP_\%20Obrazotvorche_mystetstvo_Bakalavr.pdf [in Ukrainian].

Rudnycika, O. P. (2005). Pedahohika zahalna ta mystetska [General and artistic pedagogy]. Ternopili: Navch. knygha-Boghdan [in Ukrainian].

Sadova, T. (2010). Aksiolohichnyi pidkhid u systemi pedahohichnoi metodolohi [Axiological approach in the system of pedagogical methodology]. Doshkiljna osvita [Pre-school education], 1 (27), 63-69 [in Ukrainian].

Shyshkin, Gh. O. (2013). Osobystisno-oriientovane navchannia maibutnikh uchyteliv tekhnolohii [Personality-oriented training of future technology teachers]. Naukovyj chasopys Nacionaljnogho pedaghoghichnogho universytetu imeni M.P. Draghomanova [Scientific journal of the National Pedagogical University named after MP Drahomanov], 5 (40), 292-297 [in Ukrainian].

Yakimanskaya, I. S. (2000). Tekhnologiia lichnostno-orientirovannogo obrazovaniia [Technology of personality-oriented education]. Moskva: Sentyabr [in Russian].

Zhyghinas, T. V. (2016). Aksiolohichnyi pidkhid u pidhotovtsi maibutnikh uchyteliv muzychnoho mystetstva do prosvitnytskoi roboty [Axiological approach in preparing future music teachers for educational work]. Dukhovnistj osobystosti: metodologhija, teorija i praktyka [Spirituality of personality: methodology, theory and practice], 5 (74), 85-94 [in Ukrainian].

Zaiceva, A. V. (2017). Metodychna systema formuvannia khudozhno-komunikatyvnoi kultury maibutnoho vchytelia muzyky [Methodical system of formation of artistic and communicative culture of the future music teacher]. (D diss.). Nacionaljny] universytet imeni M.P. Draghomanova. Kyiv [in Ukrainian].

\section{TSZI LEY}

National Pedagogical Drahomanov University, Ukraine

\section{SCIENCE AND PEDAGOGICAL APPROACHES TO SHAPING THE PROSPECTIVE VISUAL ART TEACHER'S ARTISTIC AND PEDAGOGICAL INTERACTION}

Increasing the efficiency of the prospective Visual Art teacher's artistic and pedagogical training is the integral constituent of solving the issues of shaping their artistic and pedagogical interaction culture; this, in its turn, requires elaborating a sustainable science and methodological basis of shaping the prospective Visual Art teacher's artistic and pedagogical interaction culture, i.e. identifying the complex of science and pedagogical approaches as the fundamentals of this process' pedagogical management.

The article under consideration deals with defining and justifying the complex of science and pedagogical approaches to shaping the prospective Visual Art teacher's artistic and pedagogical interaction culture, such as: culturological, axiological, competency-based, learner-centred.

Competency-based approach fulfilment in studying the culture of artistic and pedagogical interaction enables to identify it as one of the prospective Visual Art teacher's key common cultural and occupational competencies, that secures the ability of creating a specific domain in which the prospective Visual Art teacher ought to be prepared for creative cooperation, interlocutory thinking; to possess teamwork and business communication skills, science basics of interpersonal and occupational communication; to demonstrate artistic and communication competencies of perception, analysis, assessment and retranslation of educational information referring to Visual Art alongside with artistic and pedagogical activity.

Implementing the learner-centred approach in shaping the prospective Visual Art teacher's artistic and pedagogical interaction culture facilitates their entire personalised self-fulfilment, the evolvement of student's individual qualities, skills, 
potential opportunities within the occupational and communicational domain; nurturing the learner's positive moral and ethical qualities, realising the individual communication evolvement specifics; the artistic and pedagogical interaction needs and motivations for securing the artistic and pedagogical interaction effectiveness.

Key words: artistic and pedagogical interaction culture; science and pedagogical approach; culturological, axiological, competency-based, learner-centred science and pedagogical approaches

Стаття надійшла до редакції 14.08.2020 p.

УДК 373.5.016:51

DOI: https://doi.org/10.33989/2075-146x.2020.25.223336

\section{ЛЮБОВ ЧЕРКАСЬКА}

ORCID: 0000-0003-0871-8503

ОКСАНА МОСКАЛЕНКО

ORCID: 0000-0002-8394-4976

ОЛЕНА КОВАЛЕНКО

ORCID: 0000-0002-1990-3205

Полтавський національний педагогічний університет імені В.Г.Короленка

\section{ЗАПОБІГАННЯ ПОМИЛОК ЯК КОМПОНЕНТ КОРЕКЦІЇ РЕЗУЛЬТАТІВ НАВЧАННЯ УЧНІВ У СИСТЕМІ УРОКІВ МАТЕМАТИКИ}

У статті розкриваються особливості роботи із запобігання учнівських помилок на уроках математики різних типів, обгрунтовується вибір методів навчальної корекції.

Ключові слова: навчальний процес, корекція результатів навчання, запобігання помилок, контроль знань і вмінь учнів, уроки математики

Переорієнтація процесу навчання 3 інформативної форми на розвиток особистості людини, запровадження компетентнісного, особистісно орієнтованого, діяльнісного підходів до навчання зумовлює необхідність удосконалення структури освітнього процесу, долучення до нього процедури корекції результатів навчання кожного учня. Пошуку шляхів оптимізації навчально-виховного процесу, підвищенню його ефективності присвячені дослідження І. Акуленко, Ю. Бабанського, Л. Зоріної, В. Моторіної, В. Онищука, 3. Слєпкань, Н. Тарасенкової та ін. Особливу увагу в них приділено питанням налагодження та постійного функціонування зворотного зв'язку між учителем та учнем, а також систематичного здійснення корекції результатів навчання учнів. Окремі аспекти проблеми проведення корекції результатів навчання учнів розкриваються в працях О. Артемова, Я. Бродського, О. Глюзи, Г. Іщенко, Н. Тарасенкової, Т. Хмари та ін.

Однак, багато важливих проблем на сьогодні залишаються не розв'язаними i потребують подальших досліджень: встановлення загальнодидактичних та методичних вимог до організації корекції результатів навчання учнів математики у сучасних умовах, визначення ііі місця й функцій у навчальному процесі, пошук ефективних видів, форм, методів і засобів ііі реалізації.

Метою статті є дослідження можливостей ефективного використання корекції знань і вмінь учнів у процесі навчання математики. Завдання статті полягають у визначенні місця корекції результатів навчання учнів в освітньому процесі, встановленні іiі структурних компонентів, виділенні дидактичного інструментарію роботи 3 попередження учнівських помилок та дослідженні перспектив його практичного застосування на уроках математики різних типів.

Аналіз широкої джерельної бази відповідної тематики, експериментальних досліджень зумовив тлумачення терміну «корекція» як процесу, спрямованого на попередження і своєчасне виправлення помилок, а також ліквідацію прогалин у знаннях та вміннях окремих учнів (Черкаська, 2009, с. 56). Відповідно до сформульованого означення основними складовими компонентами корекції результатів навчання є:

- профілактична робота із запобігання математичних помилок учнів;

- усунення допущених помилок (ситуативних та системних).

Процесуальний характер проведення коректування знань учнів розглянуто у роботах Н. Тарасенкової. Авторка наголошує, що «коректування може відбуватися як у процесі формування знань, так і в період підготовки до підсумкового контролю, а також після його проведення» (Тарасенкова, 2002, с. 277). Для нашого дослідження важливим $є$ висновок про необхідність здійснення корекції математичної підготовки учнів на всіх етапах навчання: «на підготовчих уроках до теми, коли відбувається актуалізація базових знань учнів, утворюється систематизована й узагальнена основа для вмотивованого, усвідомленого набуття школярами нових знань; під час формування нових 